\title{
Revascularisation versus medical treatment in patients with stable coronary artery disease: network meta-analysis
}

\author{
(a) (1) $\Theta$ OPEN ACCESS
}

\begin{abstract}
Stephan Windecker, Stefan Stortecky, Giulio G Stefanini, Bruno R daCosta, Anne Wilhelmina Rutjes, Marcello Di Nisio, Maria G Siletta, Ausilia Maione, Fernando Alfonso, Peter M Clemmensen, Jean-Philippe Collet, Jochen Cremer, Volkmar Falk, Gerasimos Filippatos, Christian Hamm, Stuart Head, Arie Pieter Kappetein, Adnan Kastrati, Juhani Knuuti, Ulf Landmesser, Günther Laufer, Franz-Joseph Neumann, Dimitri Richter, Patrick Schauerte, Miguel Sousa Uva, David P Taggart, Lucia Torracca, Marco Valgimigli, William Wijns, Adam Witkowski, Philippe Kolh, Peter Juni
\end{abstract}

\begin{abstract}
Objective To investigate whether revascularisation improves prognosis compared with medical treatment among patients with stable coronary artery disease.

Design Bayesian network meta-analyses to combine direct within trial comparisons between treatments with indirect evidence from other trials while maintaining randomisation.

Eligibility criteria for selecting studies A strategy of initial medical treatment compared with revascularisation by coronary artery bypass grafting or Food and Drug Administration approved techniques for percutaneous revascularization: balloon angioplasty, bare metal stent, early generation paclitaxel eluting stent, sirolimus eluting stent, and zotarolimus eluting (Endeavor) stent, and new generation everolimus eluting stent, and zotarolimus eluting (Resolute) stent among patients with stable coronary artery disease.
\end{abstract}

Data sources Medline and Embase from 1980 to 2013 for randomised trials comparing medical treatment with revascularisation.

Main outcome measure All cause mortality.

Results 100 trials in 93553 patients with 262090 patient years of follow-up were included. Coronary artery bypass grafting was associated with a survival benefit (rate ratio $0.80,95 \%$ credibility interval 0.70 to 0.91 ) compared with medical treatment. New generation drug eluting stents (everolimus: $0.75,0.59$ to 0.96 ; zotarolimus (Resolute): 0.65, 0.42 to 1.00$)$ but not balloon angioplasty $(0.85,0.68$ to 1.04$)$, bare metal stents $(0.92,0.79$ to 1.05$)$, or early generation drug eluting stents (paclitaxel: $0.92,0.75$ to 1.12 ; sirolimus: $0.91,0.75$ to 1.10 ; zotarolimus (Endeavor): $0.88,0.69$ to 1.10 ) were associated with improved survival compared with medical treatment. Coronary artery bypass grafting reduced the risk of myocardial infarction compared with medical treatment $(0.79,0.63$ to 0.99$)$, and everolimus eluting stents showed a trend towards a reduced risk of myocardial infarction $(0.75,0.55$ to 1.01$)$. The risk of subsequent revascularisation was noticeably reduced by coronary artery bypass grafting $(0.16,0.13$ to 0.20$)$ followed by new generation drug eluting stents (zotarolimus (Resolute): 0.26, 0.17 to 0.40 ; everolimus: $0.27,0.21$ to 0.35 ), early generation drug eluting stents (zotarolimus (Endeavor): 0.37, 0.28 to 0.50 ; sirolimus: $0.29,0.24$ to 0.36 ; paclitaxel: $0.44,0.35$ to 0.54$)$, and bare metal stents $(0.69,0.59$ to 0.81$)$ compared with medical treatment.

Conclusion Among patients with stable coronary artery disease, coronary artery bypass grafting reduces the risk of death, myocardial infarction, and subsequent revascularisation compared with medical treatment. All stent based coronary revascularisation technologies reduce the need for revascularisation to a variable degree. Our results provide evidence for improved survival with new generation drug eluting stents but no other percutaneous revascularisation technology compared with medical treatment.

\section{Introduction}

While it is generally accepted that coronary revascularisation reduces the risk of death and myocardial infarction compared with initial medical treatment among patients with acute coronary syndromes, ${ }^{12}$ the prognostic benefit is less well established among patients with stable coronary artery disease. ${ }^{34}$ Compared with medical treatment, coronary artery bypass grafting has been shown to convey a survival advantage ${ }^{5}$; conversely, the benefit of percutaneous coronary interventions remains debatable..$^{6-8}$ None of the individual trials comparing medical treatment with percutaneous coronary intervention have shown a survival advantage, and meta-analyses revealed conflicting results, with some reporting no difference ${ }^{9}{ }^{10}$ and others suggesting a modest benefit. ${ }^{10-12}$ Notwithstanding, none of the randomised trials has been adequately powered to deal with survival, whereas treatment effects were reduced owing 
to crossover to revascularisation in a sizable proportion of patients and exclusion of high risk patients based on angiographically defined extent of coronary artery disease. ${ }^{13} 14$ Moreover, revascularisation techniques have matured over time. Nowadays, coronary artery bypass grafting systematically employs the internal mammary artery with proved long term patency and survival benefit. ${ }^{15}{ }^{16}$ Similarly, percutaneous coronary intervention has evolved with important historical transitions from the era of balloon angioplasty, ${ }^{17}$ over bare metal stents, ${ }^{18-20}$ to early generation, Food and Drug Administration approved drug eluting stents, ${ }^{21-24}$ followed more recently by new generation drug eluting stents. ${ }^{25-27}$

A large number of trials compared the different revascularisation strategies, including coronary artery bypass grafting, ${ }^{28}{ }^{29}$ balloon angioplasty, ${ }^{30}$ and percutaneous coronary intervention with bare metal stents ${ }^{13}$ or with various FDA approved drug eluting stents against medical treatment, ${ }^{32}$ as well as different revascularisation strategies head to head. ${ }^{26} 33$ 34

Network meta-analysis allows a unified analysis of the entire set of available trials by combining all direct within trial comparisons with indirect between trial comparisons of interventions constructed from trials that have one intervention in common, while fully respecting randomisation. ${ }^{35}{ }^{36} \mathrm{We}$ established a collaborative group of investigators consisting of cardiovascular surgeons and interventional and non-invasive cardiologists with expertise in the specialty of revascularisation, and conducted a network meta-analysis of all available trials to provide novel evidence in view of several recently reported trials and major technological advances in revascularisation and medical treatment.

\section{Methods}

\section{Literature search and study selection}

We searched Medline and Embase from 1980 to June 2013, using the methodological filters proposed by the Cochrane Collaboration to search for randomised clinical trials (see supplementary appendix). In addition, we hand searched reference lists of relevant reviews. Two investigators (GS, SS) assessed reports for eligibility. To be included in the analysis, studies had to be randomised controlled trials in patients with symptomatic or asymptomatic stable coronary artery disease or in unselected patient populations. Trials had to have a clinical follow-up duration of at least six months and were required to randomise at least 100 patients per trial arm. Patients had to be randomised to medical treatment, coronary artery bypass grafting, or percutaneous coronary intervention using balloon angioplasty, bare metal stents, early generation stent systems (paclitaxel eluting Taxus stent (Boston Scientific, Natick, MA), sirolimus eluting Cypher stent (Cordis, Miami Lakes, FL), zotarolimus eluting Endeavor stent (Medtronic Cardiovascular, Santa Rosa, CA)) or new generation stent systems (zotarolimus eluting Resolute stent (Medtronic Cardiovascular, Santa Rosa, CA) and everolimus eluting Xience/Promus stent (Abbott Vascular, Santa Clara, CA and Boston Scientific, Natick, MA)) approved by the FDA. We excluded trials in patients with acute myocardial infarction (ST segment elevation myocardial infarction or non-ST segment elevation myocardial infarction) and symptom onset less than 72 hours, trial arms with polymer or carbon coated bare metal stents, and trial arms with non-FDA approved drug eluting stents.

\section{Data collection and outcomes}

Four investigators (MdN, MGS, AM, or AR) independently extracted data, with disagreement resolved in consultation with another investigator (SS, GS, or PJ). We prespecified all cause mortality as the primary outcome, and myocardial infarction, a composite of death or myocardial infarction, and subsequent revascularisation as secondary outcomes. Subsequent revascularisation was defined as percutaneous or surgical revascularisation of the target lesion. If rates of target lesion revascularisation were not reported, we used rates of target vessel revascularisation or any revascularisation as a proxy measure. We extracted outcome data at the follow-up closest to five years. We assessed three key domains of internal validity, concealment of allocation, blind adjudication of outcomes, and the inclusion of all randomised participants in the analysis according to the intention to treat principle (see supplementary appendix).

\section{Statistical analysis}

The network meta-analysis was based on a bayesian random effects Poisson regression model, which preserves randomised treatment comparisons within trials. ${ }^{36-39}$ The model uses numbers of patients experiencing an event and accumulated patient years to estimate rate ratios. The specification of nodes in the network were based on the randomised intervention or in case of strategy trials, such as COURAGE ${ }^{13}$ or FAME- $2,{ }^{32}$ on the intervention received by the majority of patients in a trial arm. Analyses were performed using Markov-Chain Monte-Carlo methods. The prior distribution for treatment effects was minimally informative: a normal distribution with a mean of 1 and a $95 \%$ reference range from 0.01 to 100 on a rate ratio scale. The prior for the between trial variance $\tau^{2}$, which we assumed to be equal across comparisons, was based on empirical evidence derived from semi-objective outcomes of head to head comparisons ${ }^{40}$ : a $\log$ normal distribution with a geometric mean of $\tau^{2}$ of 0.04 and a $95 \%$ reference range from 0.001 to 1.58 . Rate ratios were estimated from the median and corresponding $95 \%$ credibility intervals from the 2.5th and 97.5th centiles of the posterior distribution. We performed primary analyses in all trials; secondary analyses were restricted to contemporary trials with start of patient enrolment in 1999 or later, which corresponds to the start of patient enrolment in COURAGE. ${ }^{13}$ We performed sensitivity analyses restricted to trials with adequate concealment of allocation; restricted to trials with blinded adjudication of events; restricted to trials with analysis according to the intention to treat principle; excluding trials that assigned patients to revascularisation with coronary artery bypass grafting; excluding "all comer" trials in unselected populations and trials in patients post-myocardial infarction, defined as patients with a history of myocardial infarction more than 72 hours to three months before randomisation; excluding trials with less than two years' follow-up; excluding trials with more than $10 \%$ of patients lost to follow-up; and performing bayesian random effects meta-analyses for all available direct randomised comparisons. In additional sensitivity analyses, we used different priors for $\tau^{2}$ and used frequentist network meta-analyses to calculate rate ratios and risk ratios without the use of priors. To examine the data for small study effects, we constructed comparison adjusted funnel plots (see supplementary appendix). Convergence was deemed to be achieved if plots of the Gelman-Rubin statistics ${ }^{41}$ indicated that widths of pooled runs and individual runs stabilised around the same value and their ratio was around 1 . Given these criteria, we based our calculations on the 20001 to 50000 iterations, discarding the first 20000 iterations as burn-in. We examined the inconsistency of the network by calculating loop specific inconsistency factors, and an omnibus test to derive an overall $\mathrm{P}$ value for inconsistency, which took into account multiple testing of potentially correlated 
inconsistency factors. ${ }^{42}$ Inconsistent loops were examined individually for sources of inconsistency. Statistical heterogeneity between trials was estimated from the median between trial variance $\tau^{2}$ observed in the posterior distribution, and goodness of fit of the model was assessed using residual deviances. ${ }^{38}$ Analyses were done in Stata 12.1 and WinBUGS 1.4 .

\section{Results \\ Characteristics of trials and patients}

Supplemental figure 1 presents the flow chart of the study and summarises the process of identifying trials. We screened the titles and abstracts of 14888 potentially eligible reports, examined the full text of 620 articles, and identified 399 articles on 100 trials that met our inclusion criteria. Table $1 \Downarrow$ presents the characteristics of the included trials. The characteristics of the patients and their diseases in the eligible studies are summarised in the supplementary appendix and the characteristics of treatment arms are summarised in table $2 \Downarrow$. Figure $1 \Downarrow$ shows the network of evidence. The bare metal stent was investigated most (50 trials) and compared with seven different interventions, whereas the zotarolimus eluting (Resolute) stent was evaluated least (four trials) and compared with three different interventions. For the primary endpoint all cause mortality, the sirolimus eluting stent and bare metal stent had the largest number of patient years (45 879 and 45467 , respectively) and the zotarolimus eluting (Resolute) stent the lowest number (3384 patient years). Overall, 93553 patients were randomised and we included follow-up of 260090 patient years in the analysis of the primary endpoint.

In general, trials were considered to be of high methodological quality. Appropriate methods of allocation concealment were described for 71 trials (71\%). Fifty six trials (56\%) reported blind adjudication of clinical outcomes, and for 69 trials (69\%) we were able to include all randomised patients into the analysis according to the intention to treat principle. Supplementary table 2 presents the raw numbers of events separately for each trial at the follow-up closest to five years. Supplementary table 3 provides a breakdown of the number of patients, events, and accumulated patient years by intervention. Figure $2 \Downarrow$ provides the cumulative number of patients randomly assigned to different types of intervention over time. Figure $3 \Downarrow$ presents the rate ratios of clinical outcomes of revascularisation compared with medical treatment.

\section{All cause mortality}

Ninety five trials including 93553 randomised patients and 5346 accumulated events contributed to the analysis of all cause mortality. Compared with a strategy of initial medical treatment, revascularisation using coronary artery bypass grafting reduced all cause mortality by $20 \%$ (rate ratio $0.80,95 \%$ credibility interval 0.70 to 0.91 ). Percutaneous coronary intervention with new generation drug eluting stents, but no other percutaneous coronary intervention technology, was also associated with reduced mortality compared with medical treatment (everolimus eluting: $0.75,0.59$ to 0.96 ; zotarolimus eluting (Resolute): 0.65, 0.42 to 1.00 ). The estimated rate ratios for mortality were below 1 , but inconclusive for revascularisation with balloon angioplasty $(0.85,0.68$ to 1.04$)$, bare metal stents $(0.92,0.79$ to 1.05$)$, and early generation drug eluting stents (paclitaxel eluting: 0.92, 0.75 to 1.12 ; sirolimus eluting: $0.91,0.75$ to 1.10 ; zotarolimus eluting (Endeavor): $0.88,0.69$ to 1.10 ).

\section{Myocardial infarction}

Ninety two trials including 90472 randomised patients contributed to the endpoint analysis of myocardial infarction (see supplementary tables 2 and 3). Overall, 5796 events were reported during 243031 patient years and contributed to the analysis of myocardial infarction. Revascularisation using coronary artery bypass grafting compared with medical treatment reduced myocardial infarction during the observational period by $21 \%(0.79,0.63$ to 0.99$)$. All percutaneous coronary interventions, except bare metal stent $(1.04,0.84$ to 1.27$)$ and paclitaxel eluting stent $(1.18,0.88$ to 1.54$)$, showed evidence for a relevant but inconclusive reduction of myocardial infarction, with point estimates below 1 for balloon angioplasty $(0.88,0.70$ to 1.11$)$, sirolimus eluting stent $(0.94,0.71$ to 1.22$)$, zotarolimus eluting (Endeavor) stent ( $0.80,0.56$ to 1.10$)$, zotarolimus eluting (Resolute) stent $(0.82,0.52$ to 1.26 ), and everolimus eluting stent $(0.75,0.55$ to 1.01$)$.

\section{Composite of death or myocardial infarction}

Eighty eight trials including 89373 randomised patients and 8936 accumulated events during 233030 patient years contributed to the analysis of the composite endpoint death or myocardial infarction (see supplementary tables 2 and 3 ). Compared with medical treatment, revascularisation using coronary artery bypass grafting, balloon angioplasty, and everolimus eluting stent was associated with a significant reduction of death or myocardial infarction by $19 \%(0.81,0.70$ to 0.94$), 17 \%$ ( $0.83,0.70$ to 0.97$)$, and $22 \%(0.78,0.63$ to 0.96$)$, respectively. No other percutaneous revascularisation technology was effective in showing a significant reduction in death or myocardial infarction, although point estimates were in favour of revascularisation with sirolimus eluting stent $(0.96,0.79$ to $1.13)$, zotarolimus eluting (Endeavor) stent ( $0.85,0.67$ to 1.05$)$, and zotarolimus eluting (Resolute) stent (0.81, 0.59 to 1.10$)$.

\section{Subsequent revascularisation}

Ninety four trials in 90282 patients contributed to the analysis of subsequent revascularisation (see supplementary tables 2 and $3)$. Subsequent coronary revascularisation events were reported in 11619 patients during the follow-up duration of 234693 patient years and contributed to the analysis of subsequent revascularisation.

Compared with medical treatment, revascularisation with coronary artery bypass grafting was effective in reducing subsequent revascularisation by $84 \%(0.16,0.13$ to 0.20$)$. Revascularisation using coronary stents was associated with a reduction in subsequent revascularisation for bare metal stent ( $0.44,0.59$ to 0.82$)$, paclitaxel eluting stent $(0.44,0.35$ to 0.55$)$, sirolimus eluting stent $(0.29,0.24$ to 0.36$)$, zotarolimus eluting (Endeavor) stent $(0.38,0.29$ to 0.51$)$, zotarolimus eluting (Resolute) stent $(0.26,0.17$ to 0.40$)$, and everolimus eluting stent $(0.27,0.21$ to 0.35$)$. Revascularisation with balloon angioplasty showed similar risks of subsequent revascularisation compared with medical treatment $(0.97,0.82$ to 1.16$)$.

\section{Restriction to contemporary trials}

Figure $4 \Downarrow$ presents results from analyses restricted to 88 contemporary trials which were initiated in 1999 or later, in 85 720 patients. Compared with the main analysis, point estimates of the rate ratio of all cause mortality moved closer to the null effect line, and $95 \%$ credibility intervals became wider, with a rate ratio of 0.85 for coronary artery bypass grafting $(0.72$ to $1.00), 0.82$ for everolimus eluting stent ( 0.65 to 1.03$)$, and 0.71 for zotarolimus eluting (Resolute) stent (0.46 to 1.11) compared 
with medical treatment. For myocardial infarction, the rate ratio for coronary artery bypass grafting moved towards more benefit $(0.48,0.37$ to 0.64$)$, and results became statistically more robust for the everolimus eluting stent $(0.73,0.57$ to 0.95$)$. For the composite of death or myocardial infarction and for revascularisation, results were similar to the main analysis.

\section{Additional analyses}

Supplementary table 4 presents rankings of different interventions compared with medical treatment in analyses of all trials, and supplementary table 5 shows the rankings in analyses of contemporaneous trials only. Table $3 \Downarrow$ presents results of sensitivity analyses. Point estimates of treatment effects were similar to those derived for the main analysis for all outcomes and interventions, and overlapping 95\% credibility intervals indicated that estimates from all sensitivity analyses, including conventional random effects meta-analyses of pairwise comparisons, were compatible with the main analysis.

Supplementary table 6 presents estimated rate ratios of all possible comparisons from conventional meta-analysis of direct randomised comparisons and network meta-analysis; estimates from network and conventional meta-analysis, where available, were compatible. Supplementary figure 2 presents comparison adjusted funnel plots, without evidence of asymmetry.

Supplementary table 7 presents results based on the use of different priors in bayesian analyses and frequentist network meta-analyses using rate ratios or risk ratios. Estimates remained robust to the use of different assumptions.

\section{Model fit, heterogeneity between trials, and consistency of the network}

Model fit was adequate (see supplementary table 8) and heterogeneity between trials low for all outcomes (range of $\tau^{2}$ across outcomes 0.003 to 0.047 ; supplementary table 9 ). There was no evidence of inconsistency for the primary outcome of overall mortality (P for inconsistency $=0.98$ ), and $95 \%$ credibility intervals of all loop specific inconsistency factors overlapped the null (see supplementary figure 3 ). For the composite of death or myocardial infarction, $95 \%$ credibility intervals of two correlated loops, both involving coronary artery bypass grafting, did not cross the null, but the overall test for inconsistency was negative ( $\mathrm{P}$ for inconsistency=0.27). For myocardial infarction, 95\% credibility intervals of three loops did not overlap the null, two involving coronary artery bypass grafting, and the overall test for inconsistency was positive ( $\mathrm{P}$ for inconsistency $=0.015$ ). For revascularisation, 95\% credibility intervals of four loops did not overlap the null, three involving coronary artery bypass grafting, again with a positive overall test for inconsistency ( $\mathrm{P}$ for inconsistency $<0.001)$. After restriction to contemporary trials, model fit remained adequate (see supplementary table 8) and heterogeneity between trials low for all outcomes (see supplementary table 9). Signals of inconsistency completely disappeared for myocardial infarction but persisted for revascularisation (see supplementary figure 4). Likely sources of inconsistency in the analysis of myocardial infarction were the 12 coronary artery bypass grafting trials initiated before 1999, which yielded a pooled rate ratio of 0.99 compared with medical treatment, balloon angioplasty or bare metal stent (95\% credibility interval 0.81 to $1.20, \tau^{2}=0.050$ ) compared with the six contemporary coronary artery bypass grafting trials, which yielded a pooled ratio of 0.49 compared with medical treatment or early generation drug eluting stents $\left(0.40\right.$ to $\left.0.60, \tau^{2}=0.000\right)$. The overall test for inconsistency became negative after exclusion of five coronary artery bypass grafting trials, which showed increases in the risk of myocardial infarction associated with coronary artery bypass grafting between $34 \%$ and $133 \%$ (see supplementary figure 5). Likely sources of inconsistency in the analysis of subsequent revascularisation were the FREEDOM and CARDia trials, which showed that the probability of subsequent revascularisation was reduced approximately three and six times with coronary artery bypass grafting compared with early generation drug eluting stents in people with diabetes, and the RESOLUTE China trial, which showed a fourfold reduction in subsequent revascularisations with the zotarolimus eluting (Resolute) stent compared with early generation drug eluting stents. The overall test for inconsistency remained positive after exclusion of these trials in the overall analysis but became negative in the analysis of contemporary trials (see supplementary figure 5), which showed only one inconsistent loop. Supplementary table 10 shows that estimates after exclusion of likely sources of inconsistency were similar to estimates from main analyses.

\section{Discussion}

The salient findings of our network meta-analysis of 100 trials in 93553 patients with stable coronary artery disease comparing revascularisation by coronary artery bypass grafting or various FDA approved percutaneous revascularisation technologies against medical treatment as initial strategy can be summarised as follows: coronary artery bypass grafting is associated with a statistically robust survival benefit compared with initial medical treatment; new generation drug eluting stents, but not balloon angioplasty, bare metal stents, or early generation drug eluting stents, are associated with improved survival compared with initial medical treatment; coronary artery bypass grafting reduces the risk of myocardial infarction compared with initial medical treatment; and the risk of subsequent revascularisation is noticeably reduced by coronary artery bypass grafting followed by new generation drug eluting stents, early generation drug eluting stents, and bare metal stents.

In secondary analyses of 88 contemporary trials in 85720 patients, which were initiated in 1999 or later, we found these results confirmed, with the exception of myocardial infarction, which showed considerably more pronounced treatment benefits of coronary artery bypass grafting and statistically more robust benefits of everolimus eluting stents. Since signals of inconsistency observed in the primary analysis of myocardial infarction completely disappeared in this secondary analysis, we deem the $52 \%$ reduction in the risk of myocardial infarction observed in the secondary analysis a more reliable estimate of the effects of contemporary revascularisation with coronary artery bypass grafting on myocardial infarction than the $21 \%$ reduction found in the primary analysis.

The most important finding of the present analysis is that several revascularisation techniques-notably, coronary artery bypass grafting and new generation drug eluting stents-are associated with improved survival compared with an initial strategy of medical treatment alone among patients with stable coronary artery disease. The survival benefit over medical treatment is well established for coronary artery bypass grafting ${ }^{5}$ but novel for percutaneous coronary intervention with new generation drug eluting stents. Our study corroborates previous reports on coronary artery bypass grafting and extends the observed benefit to contemporaneous study populations included in more recent trials with more effective medical regimens, ${ }^{28}{ }^{33}$ increased use of arterial bypass grafts, and improved perioperative management, providing a statistically more robust estimate of the associated survival benefit. 
The mechanism underlying the survival benefit of both coronary artery bypass grafting and new generation drug eluting stents compared with initial medical treatment seems to be related in part to a lower risk of myocardial infarction. The lower risk of myocardial infarction with coronary artery bypass grafting compared with medical treatment is explained by the protective effect of patent grafts against proximal vessel occlusions. ${ }^{43}$ Similarly, new generation drug eluting stents—-specifically everolimus eluting stents_-were associated with a trend towards a lower risk of myocardial infarction. Compared with previously used percutaneous revascularisation techniques, new generation drug eluting stents have been consistently shown to afford a reduction in the risk of myocardial infarction and stent thrombosis. ${ }^{44}$ A recent network meta-analysis reported a profound reduction of stent thrombosis with everolimus eluting stents compared not only with other drug eluting stents but also with bare metal stents ${ }^{45}$ - a finding that is supported by experimental evidence of antithrombotic properties of everolimus eluting stents. ${ }^{46}$ Moreover, direct comparisons of everolimus eluting stents with early generation paclitaxel eluting stents and to a lesser degree with sirolimus eluting stents have shown a lower risk of myocardial infarction with everolimus eluting stents. ${ }^{25}{ }^{47}$ It is therefore likely that the improved safety profile of new generation drug eluting stents in terms of myocardial infarction and stent thrombosis translates into improved survival compared with initial medical treatment by providing effective revascularisation without the associated risk of stent related adverse effects.

Our study provides a nuanced interpretation of the benefit of percutaneous coronary intervention techniques over initial medical treatment in terms of survival and the risk of myocardial infarction, which seems to be directly related to the device type used for revascularisation. While older technologies conferred no apparent benefit compared with medical treatment, the advent of new generation drug eluting stents apparently resulted in a survival benefit. A previous network meta-analysis comparing percutaneous coronary intervention with medical treatment was limited to the inclusion of early generation paclitaxel eluting stents and sirolimus eluting stents and observed no benefit in relation to medical treatment in terms of survival and myocardial infarction. ${ }^{6}$ The present study importantly extends this analysis by the addition of new generation FDA approved drug eluting stents as well as comparisons with coronary artery bypass grafting. Against this background, the missing survival benefit of percutaneous coronary intervention compared with medical treatment in the COURAGE trial has to be interpreted in view of the device used-namely, bare metal stents. ${ }^{13}$ More recent studies comparing initial medical treatment with new generation drug eluting stents, such as ISCHEMIA (ClinicalTrials.gov NCT01471522), have the potential to disclose a benefit in ischaemic endpoints in favour of drug eluting stents. Enrolment into FAME II was interrupted early after interim analyses disclosed an excess of primary endpoint events among medically treated patients largely driven by urgent revascularisation procedures, which in about half of cases had evidence of ongoing ischaemia on electrocadiography or myocardial infarction. ${ }^{32}$

Coronary artery bypass grafting resulted in the strongest reduction in the need for revascularisation compared with medical treatment ( $>80 \%)$, which was superior to any percutaneous coronary intervention technology, including new generation drug eluting stents. Among percutaneous revascularisation technologies, continuous progress in the need of revascularisation compared with medical treatment was observed over time, which was reduced by approximately $30 \%$ with bare metal stents, $60 \%$ with early generation paclitaxel eluting stents and zotarolimus eluting (Endeavor) stent, and more than $70 \%$ with early generation sirolimus eluting stents and new generation everolimus eluting stents and the zotarolimus eluting (Resolute) stent compared with medical treatment. Of note, the potent reduction in revascularisation with new generation drug eluting stents was not associated with any safety concerns. In fact, new generation everolimus eluting stents combined one of the best efficacy profiles among drug eluting stents with improved survival and a trend towards a lower risk of myocardial infarction compared with medical treatment alone. Notwithstanding, even new generation drug eluting stents remained less effective than coronary artery bypass grafting for risk of subsequent revascularisation. This is important as percutaneous coronary intervention irrespective of device type results in less complete revascularisation. Therefore the selection of revascularisation modality remains important, particularly among patients with advanced coronary artery disease.

\section{Limitations of this study}

The present analysis has to be interpreted in view of several limitations. Firstly, any revascularisation technique, coronary artery bypass grafting, or percutaneous coronary intervention is associated with a risk of periprocedural myocardial infarction, which is typically diagnosed by increases in biomarkers despite the absence of symptoms or electrocardiographic changes, and the prognostic importance of periprocedural myocardial infarction remains disputed. In our analysis we were, however, unable to distinguish between periprocedural and spontaneous myocardial infarction. Several studies indicate that preprocedural rather than post-procedural increases in biomarkers are associated with impaired prognosis ${ }^{48}$ and that only large periprocedural myocardial infarctions are associated with poor outcome. ${ }^{49}$ This is of importance, as a recent meta-analysis comparing percutaneous coronary intervention with initial medical treatment reported a lower risk of spontaneous myocardial infarction with percutaneous coronary intervention, which was offset by an increased risk of periprocedural myocardial infarction. ${ }^{10}$ A distinction of different types of myocardial infarction could therefore have improved our understanding of the mechanisms behind the observed survival benefit with coronary artery bypass grafting and new generation drug eluting stents. Since periprocedural myocardial infarctions preferentially occur among patients undergoing revascularisation, a restriction of the analysis to spontaneous myocardial infarction would have resulted in a more pronounced reduction in myocardial infarction with revascularisation.

Secondly, our analysis was based on the intention to treat principle, with randomised patients analysed in the group to which they were originally allocated irrespective of subsequent crossovers to revascularisation among patients allocated to medical treatment. This will have resulted in an underestimation of the true benefits of revascularisation.

Thirdly, some will argue that the inclusion of stable patients with recent myocardial infarction and trials with all comer populations including patients with acute coronary syndromes may have biased results in favour of revascularisation. However, a sensitivity analysis excluding trials in these patient populations yielded much the same results as the primary analysis (table 3).

Fourthly, the trials included in the network meta-analysis were performed over a period of several decades, during which clinical practice and optimal medical treatment for patients with coronary artery disease have evolved. Although we cannot 
exclude that changes in medical treatment over time have affected the results of this analysis, we deem this unlikely. Our analysis preserves randomised treatment comparisons within trials, statistical heterogeneity was low for all outcomes, our model with its assumptions fitted the trial data adequately, and there was no evidence of inconsistency for the primary outcome of all-cause mortality. Sources of residual inconsistency for myocardial infarction and subsequent revascularisation were explained by reasons other than concomitant medical treatment.

Fifthly, the results of the current analysis are derived from patient populations enrolled into randomised trials and may not necessarily apply to all patients encountered in routine clinical practice. Moreover, diagnostic angiography preceded randomisation in most strategy trials comparing revascularisation with medical treatment, which is likely to have resulted in the exclusion of higher risk patients.

Sixthly, in the absence of individual patient data we were forced to assume in the analysis that event rates in each trial arm were constant over time, when in reality event rates are likely to be higher during the first 30 days after randomisation. ${ }^{35} \mathrm{~A}$ sensitivity analysis of risk ratios, which does not make this assumption, showed nearly identical results, however. In addition, we assumed that the between trial variance $\tau^{2}$ is equal across comparisons, as is commonly done in network meta-analysis. This may be criticised, but was inevitable, since it allowed us to borrow strength for estimating heterogeneity across different comparisons, when some comparisons were based on a few or even a single trial only. ${ }^{50}$

Seventhly, the absence of individual patient data means that the present analysis provides average risk estimates and does not allow the evaluation of specific subgroups. It remains to be determined whether the observed treatment effects are consistent among specific high risk patient populations, such as patients with multivessel disease, diabetes, or left ventricular dysfunction, and it cannot be excluded that the advantages of coronary artery bypass grafting are more pronounced in certain subgroups of patients than observed on average in our analysis.

Finally, we were unable to distinguish between the angiographic extent of severity of coronary artery disease and functional extent of ischaemic myocardium from the data extracted for this analysis. Recent changes in clinical practice guidelines, however, highlight the importance of functional lesion severity before revascularisation. An individual patient data network meta-analysis, even though demanding, would enable the limitations discussed here to be addressed.

Using network meta-analysis, we included data from 100 trials in 93553 patients. Our model fully preserved randomisation within each trial but integrated evidence from direct and indirect comparisons to borrow strength from the entire network of trials. ${ }^{35}$ Our approach resulted in a gain in statistical precision, particularly for mortality and myocardial infarction that had only been imprecisely estimated in previous analyses. Our model is based on relative treatment effects ( $\log$ rate ratios), and variations in patient characteristics and medical co-interventions between trials are accounted for in the analysis by preserving randomised comparisons within each trial. Network meta-analysis makes similar assumptions to standard meta-analysis, but requires that these assumptions hold over the entire set of trials of the network. Additional assumptions, which are specific for network meta-analysis, are that the model fits the data and that the network of trials is consistent, with no relevant differences in estimates between direct and indirect comparisons. In view of low statistical heterogeneity, a lack of inconsistency, and excellent model fit, it is likely that these assumptions were fully satisfied over the entire set of trials covering a period of more than 30 years for the primary outcome of all cause mortality. For myocardial infarction, the secondary analysis restricted to contemporaneous trials is likely to be more reliable than the primary analysis of all trials, since signals of inconsistency initially found for myocardial infarction completely disappeared in the restricted analysis. For the outcome of subsequent revascularisation, we found evidence of inconsistency in both primary and secondary analysis, even though model fit was adequate and heterogeneity between trials low. In view of the magnitude of observed average effects, this does not, however, invalidate our conclusions that coronary artery bypass grafting is associated with the largest benefits on this outcome, followed by new generation drug eluting stents.

\section{Conclusions}

Among patients with stable coronary artery disease, coronary artery bypass grafting reduces the risk of death, myocardial infarction, and the need for revascularisation compared with medical treatment. All stent based percutaneous coronary interventions reduce the need for revascularisation to a variable degree. Our results provide evidence for improved survival with new generation drug eluting stents but no other percutaneous coronary intervention compared with medical treatment.

Collaboration coordinating centre: Department of Cardiology, University Hospital Bern, Bern University Hospital, Bern, Switzerland and the Institute of Social and Preventive Medicine, University of Bern, Bern, Switzerland. Stephan Windecker, Stefan Stortecky, Giulio G Stefanini, Bruno R da Costa, Anne W Rutjes, Marcello di Nisio, Maria G Silletta, Ausilia Maione, and Peter Jüni.

Writing committee: Stephan Windecker, Stefan Stortecky, Giulio G Stefanini, Bruno R da Costa, Anne W Rutjes, Marcello di Nisio, Maria G Silletta, Ausilia Maione, Fernando Alfonso, Peter M Clemmensen, Jean-Philippe Collet, Jochen Cremer, Volkmar Falk, Gerasimos Filippatos, Christian Hamm, Stuart J Head, A Pieter Kappetein, Adnan Kastrati, Juhani Knuuti, Ulf Landmesser, Günther Laufer, Franz-Josef Neumann, Dimitri Richter, Patrick Schauerte, Miguel Sousa Uva, David Taggart, Lucia Torracca, Marco Valgimigli, William Wijns, Adam Witkowski, Philippe Kolh, and Peter Jüni.

Contributors: SW and PJ conceived and designed the study. AWR and MdN completed the literature search and coordinated the extraction of data in collaboration with MGS and AM. SW, SS, GGS, BdC, and PJ performed and interpreted the analysis in collaboration with PK, FA, PMC, JPC, JC, VF, GF, CH, SJH, APK, AK, JK, UL, GL, FJN, DR, PS, MSU, DT, LT, MV, WW, and AW. SW, SS, and PJ wrote the first draft of the manuscript. All authors critically revised the manuscript for important intellectual content and approved the final version. SW and PJ provided administrative, technical, and logistical support. SW and $\mathrm{SS}$ contributed equally to this manuscript. SW and PJ are guarantors of the study.

Funding: This study was supported by intramural funds from the Department of Cardiology, Bern University Hospital, and the Institute of Social and Preventive Medicine, University of Bern, Switzerland.

Competing interests: All authors have completed the ICMJE uniform disclosure form at www.icmje.org/coi_disclosure.pdf. SW has received research grants to the institution from St Jude Medical and Biotronik. $\mathrm{PJ}$ is an unpaid steering committee or statistical executive committee member of trials funded by Abbott Vascular, Biosensors, Medtronic, and Johnson \& Johnson. CTU Bern, which is part of the University of Bern, has a staff policy of not accepting honorariuma or consultancy fees. However, CTU Bern is involved in the design, conduct, or analysis of clinical studies funded by Abbott Vascular, Ablynx, Amgen,

AstraZeneca, Biosensors, Biotronic, Boehrhinger Ingelheim, Eisai, Eli 


\section{What is already known on this topic}

Coronary artery bypass grafting has been shown to improve survival compared with a strategy of initial medical treatment among patients with stable coronary artery disease

Percutaneous coronary intervention compared with a strategy of initial medical treatment has not been associated with a survival advantage to date

Clinical outcomes have been improved by revascularisation techniques with systematic use of the internal mammary artery in case of coronary artery bypass grafting and important transitions in case of percutaneous revascularisation technology

\section{What this study adds}

Coronary artery bypass grafting and new generation drug eluting stents are associated with a survival benefit compared with a strategy of initial medical treatment

Coronary artery bypass grafting reduces the risk of myocardial infarction, and new generation everolimus eluting stents are associated with a trend towards a reduced risk of myocardial infarction compared with initial medical treatment

The risk of subsequent revascularisation is noticeably reduced by coronary artery bypass grafting followed by new generation drug eluting stents, early generation drug eluting stents, and bare metal stents

Lilly, Exelixis, Geron, Gilead Sciences, Nestlé, Novartis, Novo Nordisc, Padma, Roche, Schering-Plough, St Jude Medical, and Swiss Cardio Technologies. PS has received speakers' honorariums from Medtronic, Biotronik, St Jude Medical, Impulse Dynamics, BioControl during the past five years. All other members of the writing committee declare: no support from any organisation for the submitted work; no financial relationships with any organisations that might have an interest in the submitted work in the previous three years; no other relationships or activities that could appear to have influenced the submitted work.

Ethical approval: Not required.

Data sharing: No additional data available

Transparency: The lead authors (the manuscript's guarantors) affirms that the manuscript is an honest, accurate, and transparent account of the study being reported; that no important aspects of the study have been omitted; and that any discrepancies from the study as planned (and, if relevant, registered) have been explained.

1 Fox KA, Clayton TC, Damman P, Pocock SJ, de Winter RJ, Tijssen JG, et al. Long-term outcome of a routine versus selective invasive strategy in patients with non-ST-segment elevation acute coronary syndrome a meta-analysis of individual patient data. J Am Coll Cardiol 2010;55:2435-45

2 Keeley EC, Boura JA, Grines CL. Primary angioplasty versus intravenous thrombolytic therapy for acute myocardial infarction: a quantitative review of 23 randomised trials. Lancet 2003;361:13-20.

3 Pfisterer ME, Zellweger MJ, Gersh BJ. Management of stable coronary artery disease. Lancet 2010;375:763-72.

4 Simoons ML, Windecker S. Controversies in cardiovascular medicine: chronic stable coronary artery disease: drugs vs. revascularization. Eur Heart J 2010;31:530-41.

5 Yusuf S, Zucker D, Peduzzi P, Fisher LD, Takaro T, Kennedy JW, et al. Effect of coronary artery bypass graft surgery on survival: overview of 10-year results from randomised trials by the Coronary Artery Bypass Graft Surgery Trialists Collaboration. Lancet 1994:344:563-70.

6 Trikalinos TA, Alsheikh-Ali AA, Tatsioni A, Nallamothu BK, Kent DM. Percutaneous coronary interventions for non-acute coronary artery disease: a quantitative 20-yea synopsis and a network meta-analysis. Lancet 2009;373:911-8.

7 Stergiopoulos K, Brown DL. Initial coronary stent implantation with medical therapy vs medical therapy alone for stable coronary artery disease: meta-analysis of randomized controlled trials. Arch Intern Med 2012;172:312-9.

8 Wijns W, Kolh P, Danchin N, Di Mario C, Falk V, Folliguet T, et al. Guidelines on myocardial revascularization. Eur Heart J 2010;31:2501-55

9 Katritsis DG, loannidis JP. Percutaneous coronary intervention versus conservative therapy in nonacute coronary artery disease: a meta-analysis. Circulation 2005;111:2906-12.

10 Bangalore S, Pursnani S, Kumar S, Bagos PG. Percutaneous coronary intervention versus optimal medical therapy for prevention of spontaneous myocardial infarction in subjects with stable ischemic heart disease. Circulation 2013;127:769-81.

11 Schomig A, Mehilli J, de Waha A, Seyfarth M, Pache J, Kastrati A. A meta-analysis of 17 randomized trials of a percutaneous coronary intervention-based strategy in patients with stable coronary artery disease. J Am Coll Cardiol 2008:52:894-904

12 Jeremias A, Kaul S, Rosengart TK, Gruberg L, Brown DL. The impact of revascularization on mortality in patients with nonacute coronary artery disease. Am J Med 2009;122:152-61.

13 Boden WE, O'Rourke RA, Teo KK, Hartigan PM, Maron DJ, Kostuk WJ, et al. Optimal medical therapy with or without $\mathrm{PCl}$ for stable coronary disease. N Engl J Med 2007;356:1503-16

14 Kereiakes DJ, Teirstein PS, Sarembock IJ, Holmes DR Jr, Krucoff MW, O'Neill WW, et al. The truth and consequences of the COURAGE trial. J Am Coll Cardiol 2007;50:1598-603.

15 Desai ND, Cohen EA, Naylor CD, Fremes SE. A randomized comparison of radial-artery and saphenous-vein coronary bypass grafts. N Engl J Med 2004;351:2302-9.

16 Lytle BW. Prolonging patency-choosing coronary bypass grafts. N Engl J Med 2004;351:2262-4.

17 Gruntzig AR, Senning A, Siegenthaler WE. Nonoperative dilatation of coronary-artery stenosis: percutaneous transluminal coronary angioplasty. N Engl J Med 1979;301:61-8.
18 Fischman DL, Leon MB, Baim DS, Schatz RA, Savage MP, Penn I, et al. A randomized comparison of coronary-stent placement and balloon angioplasty in the treatment of coronary artery disease. Stent Restenosis Study Investigators. N Engl J Med 1994;331:496-501.

19 Serruys PW, de Jaegere P, Kiemeneij F, Macaya C, Rutsch W, Heyndrickx G, et al. A comparison of balloon-expandable-stent implantation with balloon angioplasty in patients with coronary artery disease. Benestent Study Group. N Engl J Med 1994;331:489-95.

20 Serruys PW, van Hout B, Bonnier H, Legrand V, Garcia E, Macaya C, et al. Randomised comparison of implantation of heparin-coated stents with balloon angioplasty in selected patients with coronary artery disease (Benestent II). Lancet 1998;352:673-81.

21 Stone GW, Ellis SG, Cox DA, Hermiller J, O'Shaughnessy C, Mann JT, et al. A polymer-based, paclitaxel-eluting stent in patients with coronary artery disease. N Engl J Med 2004;350:221-31.

22 Fajadet J, Wijns W, Laarman GJ, Kuck KH, Ormiston J, Munzel T, et al. Randomized, double-blind, multicenter study of the Endeavor zotarolimus-eluting phosphorylcholine-encapsulated stent for treatment of native coronary artery lesions: clinical and angiographic results of the ENDEAVOR II trial Circulation 2006:114:798-806.

23 Morice MC, Serruys PW, Sousa JE, Fajadet J, Ban Hayashi E, Perin M, et al. A randomized comparison of a sirolimus-eluting stent with a standard stent for coronary revascularization. N Engl J Med 2002;346:1773-80.

24 Moses JW, Leon MB, Popma JJ, Fitzgerald PJ, Holmes DR, O'Shaughnessy C, et al. Sirolimus-eluting stents versus standard stents in patients with stenosis in a native coronary artery. N Engl J Med 2003;349:1315-23.

25 Stone GW, Rizvi A, Newman W, Mastali K, Wang JC, Caputo R, et al. Everolimus-eluting versus paclitaxel-eluting stents in coronary artery disease. N Engl J Med 2010;362:1663-74.

26 Serruys PW, Silber S, Garg S, van Geuns RJ, Richardt G, Buszman PE, et al. Comparison of zotarolimus-eluting and everolimus-eluting coronary stents. N Eng/ J Med 2010;363:136-46.

27 Stefanini GG, Holmes DR Jr. Drug-eluting coronary-artery stents. N Engl J Med 2013;368:254-65.

28 Bonow RO, Maurer G, Lee KL, Holly TA, Binkley PF, Desvigne-Nickens P, et al. Myocardial viability and survival in ischemic left ventricular dysfunction. $N$ Engl $\mathrm{J}$ Med 2011;364:1617-25.

29 Frye RL, August P, Brooks MM, Hardison RM, Kelsey SF, MacGregor JM, et al. A randomized trial of therapies for type 2 diabetes and coronary artery disease. $N$ Engl $J$ Med 2009;360:2503-15

30 Erne P, Schoenenberger AW, Burckhardt D, Zuber M, Kiowski W, Buser PT, et al. Effects of percutaneous coronary interventions in silent ischemia after myocardial infarction: the SWISSI II randomized controlled trial. JAMA 2007;297:1985-91.

31 Coronary angioplasty versus medical therapy for angina: the second Randomised Intervention Treatment of Angina (RITA-2) trial. RITA-2 trial participants. Lancet 1997;350:461-8.

32 De Bruyne B, Pijls NH, Kalesan B, Barbato E, Tonino PA, Piroth Z, et al. Fractional flow reserve-guided $\mathrm{PCl}$ versus medical therapy in stable coronary disease. $N$ Engl $\mathrm{J} \mathrm{Med}$ 2012;367:991-1001

33 Mohr FW, Morice MC, Kappetein AP, Feldman TE, Stahle E, Colombo A, et al. Coronary artery bypass graft surgery versus percutaneous coronary intervention in patients with three-vessel disease and left main coronary disease: 5 -year follow-up of the randomised, clinical SYNTAX trial. Lancet 2013;381:629-38.

34 Farkouh ME, Domanski M, Sleeper LA, Siami FS, Dangas G, Mack M, et al. Strategies for multivessel revascularization in patients with diabetes. N Engl J Med 2012;367:2375-84.

35 Stettler C, Wandel S, Allemann S, Kastrati A, Morice MC, Schomig A, et al. Outcomes associated with drug-eluting and bare-metal stents: a collaborative network meta-analysis. Lancet 2007:370:937-48.

36 Lu G, Ades AE. Combination of direct and indirect evidence in mixed treatment comparisons. Stat Med 2004;23:3105-24.

37 Dias S, Welton NJ, Sutton AJ, Ades AE. NICE DSU technical support document 2: a generalised linear modelling framework for pairwise and network meta-analysis of randomised controlled trials. 2011. www.nicedsu.org.uk.

38 Cooper NJ, Sutton AJ, Lu G, Khunti K. Mixed comparison of stroke prevention treatments in individuals with nonrheumatic atrial fibrillation. Arch Intern Med 2006;166:1269-75.

39 Higgins JP, Whitehead A. Borrowing strength from external trials in a meta-analysis. Stat Med 1996;15:2733-49

40 Turner RM, Davey J, Clarke MJ, Thompson SG, Higgins JP. Predicting the extent of heterogeneity in meta-analysis, using empirical data from the Cochrane Database of Systematic Reviews. Int J Epidemiol 2012:41:818-27.

41 Brooks S, Gelman A. Alternative methods for monitoring convergence of iterative simulations. J Comput Graph Stat 1998;7:434-55.

42 Veroniki AA, Vasiliadis HS, Higgins JP, Salanti G. Evaluation of inconsistency in networks of interventions. Int J Epidemiol 2013;42:332-45.

43 Detre KM, Lombardero MS, Brooks MM, Hardison RM, Holubkov R, Sopko G, et al. The effect of previous coronary-artery bypass surgery on the prognosis of patients with diabetes 
who have acute myocardial infarction. Bypass Angioplasty Revascularization Investigation Investigators. N Engl J Med 2000;342:989-97.

44 Stefanini GG, Baber U, Windecker S, Morice MC, Sartori S, Leon MB, et al. Safety and efficacy of drug-eluting stents in women: a patient-level pooled analysis of randomised trials. Lancet 2013;382:1879-88.

45 Palmerini T, Biondi-Zoccai G, Della Riva D, Stettler C, Sangiorgi D, D'Ascenzo F, et al. Stent thrombosis with drug-eluting and bare-metal stents: evidence from a comprehensive network meta-analysis. Lancet 2012;379:1393-402.

46 Kolandaivelu K, Swaminathan R, Gibson WJ, Kolachalama VB, Nguyen-Ehrenreich KL, Giddings $V L$, et al. Stent thrombogenicity early in high-risk interventional settings is driven by stent design and deployment and protected by polymer-drug coatings. Circulation 2011;123:1400-9.

47 Kedhi E, Joesoef KS, McFadden E, Wassing J, van Mieghem C, Goedhart D, et al. Second-generation everolimus-eluting and paclitaxel-eluting stents in real-life practice (COMPARE): a randomised trial. Lancet 2010;375:201-9.

48 Moussa ID, Klein LW, Shah B, Mehran R, Mack MJ, Brilakis ES, et al. Consideration of a new definition of clinically relevant myocardial infarction after coronary revascularization: an expert consensus document from the Society for Cardiovascular Angiography and Interventions (SCAI). J Am Coll Cardiol 2013;62:1563-70.

49 Prasad A, Herrmann J. Myocardial infarction due to percutaneous coronary intervention. N Engl J Med 2011;364:453-64.

50 Thorlund K, Thabane L, Mills EJ. Modelling heterogeneity variances in multiple treatment comparison meta-analysis-are informative priors the better solution? BMC Med Res Methodol 2013;13:2.

\section{Accepted: 27 May 2014}

Cite this as: BMJ 2014;348:g3859

This is an Open Access article distributed in accordance with the Creative Commons Attribution Non Commercial (CC BY-NC 3.0) license, which permits others to distribute, remix, adapt, build upon this work non-commercially, and license their derivative works on different terms, provided the original work is properly cited and the use is non-commercial. See: http://creativecommons.org/licenses/by-nc/3.0/. 


\section{Tables}

Table 1 | Characteristics of randomised trials. Values are medians (ranges) unless stated otherwise

\begin{tabular}{lc} 
Characteristics & Total (n=100) \\
No of patients randomised & $510(200-8709)$ \\
\hline Average age (years) & $62(51-69)$ \\
\hline$\%$ women & $24(0-42)$ \\
\hline$\%$ with multivessel disease & $55(34-80)$ \\
\hline Left ventricular ejection fraction (\%) & $59.5(56-61.2)$ \\
\hline$\%$ of patients with diabetes & $23(16-31)$ \\
\hline Year of publication & $2007(1982-2013)$ \\
\hline Intervention arms (No of trials/No of randomised patients): & $15(7010)$ \\
\hline Medical treatment & $22(8920)$ \\
\hline Coronary artery bypass grafting & $29(7609)$ \\
\hline Percutaneous transluminal coronary angioplasty & $50(16042)$ \\
\hline Bare metal stent & $27(11541)$ \\
\hline Paclitaxel eluting stent & $39(19781)$ \\
\hline Sirolimus eluting stent & $8(8937)$ \\
\hline Zotarolimus eluting (Endeavor) stent & $4(2285)$ \\
\hline Rotarolimus eluting (Resolute) stent & $17(13272)$ \\
\hline Everolimus eluting stent & $71(71)$ \\
\hline Methodological characteristics (No (\%) of trials): & $56(56)$ \\
\hline Adequate allocation concealment & \\
\hline Blind event adjudication & \\
\hline Intention to treat analysis performed & \\
\hline
\end{tabular}


Table 2| Characteristics of treatment arms

\begin{tabular}{lccccc} 
& & \multicolumn{3}{c}{ No of events } \\
\cline { 3 - 6 } Treatment & $\begin{array}{c}\text { Follow-up (patient } \\
\text { years)* }\end{array}$ & All cause mortality & Myocardial infarction & $\begin{array}{c}\text { Death or myocardial } \\
\text { infarction }\end{array}$ & $\begin{array}{c}\text { Subsequent } \\
\text { revascularisation }\end{array}$ \\
\hline Medical treatment & 30628 & 857 & 541 & 967 & 1709 \\
\hline CABG & 38709 & 970 & 553 & 1170 & 556 \\
\hline PTCA & 17678 & 296 & 451 & 706 & 2164 \\
\hline BMS & 45467 & 852 & 946 & 1628 & 2873 \\
\hline PES & 27592 & 567 & 663 & 1104 & 1203 \\
\hline SES & 45879 & 909 & 1321 & 683 & 714 \\
\hline E-ZES & 27134 & 445 & 788 & 180 & 719 \\
\hline R-ZES & 3384 & 55 & 130 & 746 & 144 \\
\hline EES & 23619 & 395 & 403 & & 817
\end{tabular}

$\mathrm{CABG}=$ coronary artery bypass grafting; $\mathrm{PTCA}=$ percutaneous transluminal coronary angioplasty; $\mathrm{BMS}=$ bare metal stent; $\mathrm{PES}=$ paclitaxel eluting stent; $\mathrm{SES}=$ sirolimus eluting stent; E-ZES=zotarolimus eluting (Endeavor) stent; R-ZES=zotarolimus eluting (Resolute) stent; EES=everolimus eluting stent.

*For the primary endpoint all cause death. 


\begin{tabular}{|c|c|c|c|c|c|c|c|c|c|}
\hline \multicolumn{10}{|c|}{ Table 3 | Sensitivity analyses } \\
\hline \multirow[b]{2}{*}{$\begin{array}{l}\text { Outcomes by } \\
\text { interventions }\end{array}$} & \multicolumn{8}{|c|}{ Network meta-analysis } & \multirow[b]{2}{*}{$\begin{array}{c}\text { Conventional } \\
\text { meta-analysis* }\end{array}$} \\
\hline & $\begin{array}{l}\text { Allocation } \\
\text { concealed }\end{array}$ & $\begin{array}{l}\text { Adjudication } \\
\text { blinded }\end{array}$ & $\begin{array}{l}\text { Intention to } \\
\text { treat } \\
\text { analysis }\end{array}$ & $\begin{array}{l}\text { Excluding } \\
\text { CABG trials }\end{array}$ & $\begin{array}{l}\text { Excluding all } \\
\text { comer and } \\
\text { post-MI trials }\end{array}$ & $\begin{array}{l}\text { Trials with } \\
\leq 10 \% \text { lost to } \\
\text { follow-up }\end{array}$ & $\begin{array}{l}\text { Trials with } \\
\geq 24 \text { months } \\
\text { of follow-up }\end{array}$ & All trials & \\
\hline All cause mortality: & $\begin{array}{l}67 \text { trials with } \\
195142 \mathrm{PY}\end{array}$ & $\begin{array}{l}55 \text { trials with } \\
201157 \mathrm{PY}\end{array}$ & $\begin{array}{l}66 \text { trials with } \\
206937 \mathrm{PY}\end{array}$ & $\begin{array}{l}73 \text { trials with } \\
180269 \mathrm{PY}\end{array}$ & $\begin{array}{l}77 \text { trials with } \\
174343 \mathrm{PY}\end{array}$ & $\begin{array}{l}76 \text { trials with } \\
217371 \mathrm{PY}\end{array}$ & $\begin{array}{l}54 \text { trials with } \\
230503 \mathrm{PY}\end{array}$ & $\begin{array}{l}95 \text { trials with } \\
260090 \mathrm{PY}\end{array}$ & \\
\hline $\begin{array}{l}\mathrm{CABG} v \text { medical } \\
\text { treatment }\end{array}$ & $\begin{array}{c}0.83 \text { (0.69 to } \\
0.99)\end{array}$ & $\begin{array}{c}0.87(0.73 \text { to } \\
1.04)\end{array}$ & $\begin{array}{c}0.84 \text { (0.73 to } \\
0.95)\end{array}$ & - & $\begin{array}{c}0.81 \text { ( } 0.70 \text { to } \\
0.93)\end{array}$ & $\begin{array}{c}0.75 \text { (0.64 to } \\
0.87)\end{array}$ & $\begin{array}{c}0.79 \text { (0.69 to } \\
0.90)\end{array}$ & $\begin{array}{c}0.80 \text { (0.70 to } \\
0.91)\end{array}$ & $\begin{array}{c}0.77(0.57 \text { to } \\
0.98)\end{array}$ \\
\hline $\begin{array}{l}\text { PTCA } v \text { medical } \\
\text { treatment }\end{array}$ & $\begin{array}{c}0.92 \text { (0.73 to } \\
1.15)\end{array}$ & $\begin{array}{c}0.88 \text { (0.64 to } \\
1.22)\end{array}$ & $\begin{array}{c}0.91 \text { ( } 0.73 \text { to } \\
1.12)\end{array}$ & $\begin{array}{c}0.85 \text { (0.63 to } \\
1.15)\end{array}$ & $\begin{array}{c}0.85 \text { (0.68 to } \\
1.05)\end{array}$ & $\begin{array}{c}0.82 \text { (0.65 to } \\
1.02)\end{array}$ & $\begin{array}{c}0.81(0.64 \text { to } \\
1.02)\end{array}$ & $\begin{array}{c}0.85 \text { (0.68 to } \\
1.04)\end{array}$ & $\begin{array}{c}0.66(0.25 \text { to } \\
1.56)\end{array}$ \\
\hline $\begin{array}{l}\text { BMS } v \text { medical } \\
\text { treatment }\end{array}$ & $\begin{array}{c}0.96 \text { (0.77 to } \\
1.19)\end{array}$ & $\begin{array}{c}0.98 \text { (0.83 to } \\
1.15)\end{array}$ & $\begin{array}{c}0.94 \text { (0.80 to } \\
1.09)\end{array}$ & $\begin{array}{c}0.95 \text { (0.78 to } \\
1.13)\end{array}$ & $\begin{array}{c}0.92(0.77 \text { to } \\
1.06)\end{array}$ & $\begin{array}{c}0.91 \text { ( } 0.74 \text { to } \\
1.09)\end{array}$ & $\begin{array}{c}0.94 \text { (0.81 to } \\
1.09)\end{array}$ & $\begin{array}{c}0.92 \text { (0.79 to } \\
1.05)\end{array}$ & $\begin{array}{c}0.99(0.74 \text { to } \\
1.26)\end{array}$ \\
\hline \multicolumn{10}{|l|}{$\begin{array}{l}\text { Early generation } \\
\text { DES: }\end{array}$} \\
\hline $\begin{array}{l}\text { PES } v \text { medical } \\
\text { treatment }\end{array}$ & $\begin{array}{c}0.93 \text { (0.72 to } \\
1.19)\end{array}$ & $\begin{array}{c}0.95 \text { (0.75 to } \\
1.20)\end{array}$ & $\begin{array}{c}1.01(0.80 \text { to } \\
1.26)\end{array}$ & $\begin{array}{c}0.92(0.69 \text { to } \\
1.20)\end{array}$ & $\begin{array}{c}0.94 \text { (0.74 to } \\
1.18)\end{array}$ & $\begin{array}{c}0.89 \text { (0.70 to } \\
1.10)\end{array}$ & $\begin{array}{c}0.96(0.78 \text { to } \\
1.18)\end{array}$ & $\begin{array}{c}0.92 \text { (0.75 to } \\
1.12)\end{array}$ & - \\
\hline $\begin{array}{l}\text { SES } v \text { medical } \\
\text { treatment }\end{array}$ & $\begin{array}{c}0.87 \text { (0.67 to } \\
1.13)\end{array}$ & $\begin{array}{c}0.94 \text { (0.75 to } \\
1.15)\end{array}$ & $\begin{array}{c}0.95 \text { (0.76 to } \\
1.19)\end{array}$ & $\begin{array}{c}0.91 \text { (0.69 to } \\
1.17)\end{array}$ & $\begin{array}{c}1.00 \text { (0.79 to } \\
1.24)\end{array}$ & $\begin{array}{c}0.91 \text { ( } 0.72 \text { to } \\
1.13)\end{array}$ & $\begin{array}{c}0.94 \text { (0.76 to } \\
1.13)\end{array}$ & $\begin{array}{c}0.91 \text { (0.75 to } \\
1.10)\end{array}$ & - \\
\hline $\begin{array}{l}\text { E-ZES } v \text { medical } \\
\text { treatment }\end{array}$ & $\begin{array}{c}0.89 \text { (0.67 to } \\
1.18)\end{array}$ & $\begin{array}{c}0.91 \text { ( } 0.70 \text { to } \\
1.15)\end{array}$ & $\begin{array}{c}0.95 \text { ( } 0.73 \text { to } \\
1.25)\end{array}$ & $\begin{array}{c}0.88 \text { (0.65 to } \\
1.16)\end{array}$ & $\begin{array}{c}0.79(0.57 \text { to } \\
1.11)\end{array}$ & $\begin{array}{c}0.85 \text { (0.65 to } \\
1.09)\end{array}$ & $\begin{array}{c}0.91 \text { ( } 0.71 \text { to } \\
1.15)\end{array}$ & $\begin{array}{c}0.88 \text { (0.69 to } \\
1.10)\end{array}$ & - \\
\hline \multicolumn{10}{|l|}{$\begin{array}{l}\text { New generation } \\
\text { DES: }\end{array}$} \\
\hline $\begin{array}{l}\mathrm{R}-\mathrm{ZES} v \text { medical } \\
\text { treatment }\end{array}$ & $\begin{array}{c}0.65(0.41 \text { to } \\
1.03)\end{array}$ & $\begin{array}{c}0.68(0.43 \text { to } \\
1.07)\end{array}$ & NA & $\begin{array}{c}0.65 \text { (0.42 to } \\
1.02)\end{array}$ & NA & $\begin{array}{c}0.65(0.41 \text { to } \\
1.02)\end{array}$ & $\begin{array}{c}0.65 \text { (0.38 to } \\
1.11)\end{array}$ & $\begin{array}{c}0.65(0.42 \text { to } \\
1.00)\end{array}$ & - \\
\hline $\begin{array}{l}\text { EES } v \text { medical } \\
\text { treatment }\end{array}$ & $\begin{array}{c}0.76 \text { (0.58 to } \\
1.02)\end{array}$ & $\begin{array}{c}0.79(0.62 \text { to } \\
1.02)\end{array}$ & $\begin{array}{c}0.83 \text { (0.63 to } \\
1.07)\end{array}$ & $\begin{array}{c}0.75 \text { (0.56 to } \\
1.00)\end{array}$ & $\begin{array}{c}0.63(0.45 \text { to } \\
0.90)\end{array}$ & $\begin{array}{c}0.74 \text { (0.56 to } \\
0.95)\end{array}$ & $\begin{array}{c}0.81 \text { ( } 0.63 \text { to } \\
1.03)\end{array}$ & $\begin{array}{c}0.75 \text { (0.59 to } \\
0.96)\end{array}$ & $\begin{array}{c}0.33(0.03 \text { to } \\
3.16)\end{array}$ \\
\hline $\begin{array}{l}\text { Myocardial } \\
\text { infarction: }\end{array}$ & $\begin{array}{l}65 \text { trials with } \\
183637 \mathrm{PY}\end{array}$ & $\begin{array}{l}55 \text { trials with } \\
194710 \mathrm{PY}\end{array}$ & $\begin{array}{l}63 \text { trials with } \\
194515 \mathrm{PY}\end{array}$ & $\begin{array}{l}75 \text { trials with } \\
182347 \mathrm{PY} \\
\end{array}$ & $\begin{array}{l}75 \text { trials with } \\
158564 \mathrm{PY}\end{array}$ & $\begin{array}{l}74 \text { trials with } \\
203166 \mathrm{PY}\end{array}$ & $\begin{array}{l}50 \text { trials with } \\
214188 \mathrm{PY}\end{array}$ & $\begin{array}{l}92 \text { trials with } \\
243031 \mathrm{PY}\end{array}$ & \\
\hline $\begin{array}{l}\text { CABG } v \text { medical } \\
\text { treatment }\end{array}$ & $\begin{array}{c}0.77 \text { (0.53 to } \\
1.10)\end{array}$ & $\begin{array}{c}0.69(0.51 \text { to } \\
0.95)\end{array}$ & $\begin{array}{c}0.80(0.62 \text { to } \\
1.02)\end{array}$ & - & $\begin{array}{c}0.80 \text { (0.63 to } \\
1.03)\end{array}$ & $\begin{array}{c}0.78(0.59 \text { to } \\
1.01)\end{array}$ & $\begin{array}{c}0.77(0.58 \text { to } \\
1.01)\end{array}$ & $\begin{array}{l}0.79 \text { (0.63 to } \\
0.99)\end{array}$ & $\begin{array}{c}0.69(0.23 \text { to } \\
1.89)\end{array}$ \\
\hline $\begin{array}{l}\text { PTCA } v \text { medical } \\
\text { treatment }\end{array}$ & $\begin{array}{c}0.92 \text { (0.67 to } \\
1.27)\end{array}$ & $\begin{array}{c}0.92(0.67 \text { to } \\
1.26)\end{array}$ & $\begin{array}{c}0.89 \text { (0.69 to } \\
1.15)\end{array}$ & $\begin{array}{c}0.98(0.79 \text { to } \\
1.22)\end{array}$ & $\begin{array}{c}0.88 \text { (0.68 to } \\
1.12)\end{array}$ & $\begin{array}{c}0.89 \text { (0.68 to } \\
1.15)\end{array}$ & $\begin{array}{c}0.82(0.59 \text { to } \\
1.13)\end{array}$ & $\begin{array}{c}0.88 \text { (0.70 to } \\
1.11)\end{array}$ & $\begin{array}{l}0.87 \text { (0.34 to } \\
2.30)\end{array}$ \\
\hline $\begin{array}{l}\text { BMS } v \text { medical } \\
\text { treatment }\end{array}$ & $\begin{array}{c}1.02 \text { (0.73 to } \\
1.38)\end{array}$ & $\begin{array}{c}1.04(0.81 \text { to } \\
1.29)\end{array}$ & $\begin{array}{c}1.04 \text { (0.83 to } \\
1.30)\end{array}$ & $\begin{array}{c}1.11 \text { (0.94 to } \\
1.32)\end{array}$ & $\begin{array}{c}1.01(0.80 \text { to } \\
1.25)\end{array}$ & $\begin{array}{c}1.07 \text { (0.81 to } \\
1.38)\end{array}$ & $\begin{array}{c}1.02 \text { (0.77 to } \\
1.32)\end{array}$ & $\begin{array}{c}1.04 \text { (0.84 to } \\
1.27)\end{array}$ & $\begin{array}{c}1.07 \text { (0.63 to } \\
1.50)\end{array}$ \\
\hline \multicolumn{10}{|l|}{$\begin{array}{l}\text { Early generation } \\
\text { DES: }\end{array}$} \\
\hline $\begin{array}{l}\text { PES } v \text { medical } \\
\text { treatment }\end{array}$ & $\begin{array}{c}1.14 \text { (0.79 to } \\
1.67)\end{array}$ & $\begin{array}{c}1.04(0.74 \text { to } \\
1.40)\end{array}$ & $\begin{array}{c}1.33(0.92 \text { to } \\
1.87)\end{array}$ & $\begin{array}{c}1.05(0.82 \text { to } \\
1.36)\end{array}$ & $\begin{array}{c}1.28(0.92 \text { to } \\
1.74)\end{array}$ & $\begin{array}{c}1.21(0.87 \text { to } \\
1.64)\end{array}$ & $\begin{array}{c}1.20(0.81 \text { to } \\
1.73)\end{array}$ & $\begin{array}{c}1.18 \text { (0.88 to } \\
1.54)\end{array}$ & - \\
\hline $\begin{array}{l}\text { SES } v \text { medical } \\
\text { treatment }\end{array}$ & $\begin{array}{c}0.89 \text { (0.61 to } \\
1.28)\end{array}$ & $\begin{array}{c}0.84 \text { (0.61 to } \\
1.12)\end{array}$ & $\begin{array}{c}1.08 \text { (0.76 to } \\
1.49)\end{array}$ & $\begin{array}{c}0.82 \text { (0.64 to } \\
1.06)\end{array}$ & $\begin{array}{c}1.05 \text { (0.77 to } \\
1.40)\end{array}$ & $\begin{array}{c}0.98 \text { (0.70 to } \\
1.32)\end{array}$ & $\begin{array}{c}0.90(0.62 \text { to } \\
1.27)\end{array}$ & $\begin{array}{c}0.94 \text { (0.71 to } \\
1.22)\end{array}$ & - \\
\hline $\begin{array}{l}\text { E-ZES } v \text { medical } \\
\text { treatment }\end{array}$ & $\begin{array}{c}0.80 \text { (0.52 to } \\
1.20)\end{array}$ & $\begin{array}{c}0.73 \text { (0.50 to } \\
1.02)\end{array}$ & $\begin{array}{c}0.99 \text { (0.66 to } \\
1.46)\end{array}$ & $\begin{array}{c}0.76 \text { (0.57 to } \\
1.01)\end{array}$ & $\begin{array}{c}0.76 \text { ( } 0.49 \text { to } \\
1.14)\end{array}$ & $\begin{array}{c}0.84 \text { (0.56 to } \\
1.20)\end{array}$ & $\begin{array}{c}0.75 \text { (0.48 to } \\
1.14)\end{array}$ & $\begin{array}{c}0.80 \text { (0.56 to } \\
1.10)\end{array}$ & - \\
\hline \multicolumn{10}{|l|}{$\begin{array}{l}\text { New generation } \\
\text { DES: }\end{array}$} \\
\hline $\begin{array}{l}\text { R-ZES } v \text { medical } \\
\text { treatment }\end{array}$ & $\begin{array}{c}0.78 \text { (0.48 to } \\
1.27)\end{array}$ & $\begin{array}{c}0.75 \text { (0.48 to } \\
1.17) \\
\end{array}$ & NA & $\begin{array}{c}0.73(0.50 \text { to } \\
1.04)\end{array}$ & NA & $\begin{array}{c}0.85 \text { (0.53 to } \\
1.33)\end{array}$ & $\begin{array}{c}0.79 \text { (0.36 to } \\
1.71)\end{array}$ & $\begin{array}{c}0.82(0.52 \text { to } \\
1.26)\end{array}$ & - \\
\hline $\begin{array}{l}\text { EES } v \text { medical } \\
\text { treatment }\end{array}$ & $\begin{array}{c}0.72 \text { (0.49 to } \\
1.07)\end{array}$ & $\begin{array}{c}0.70 \text { (0.50 to } \\
0.96)\end{array}$ & $\begin{array}{c}0.89(0.60 \text { to } \\
1.27) \\
\end{array}$ & $\begin{array}{l}0.67 \text { (0.51 to } \\
0.89)\end{array}$ & $\begin{array}{c}0.84(0.57 \text { to } \\
1.22)\end{array}$ & $\begin{array}{c}0.77(0.54 \text { to } \\
1.07)\end{array}$ & $\begin{array}{c}0.70 \text { (0.46 to } \\
1.06)\end{array}$ & $\begin{array}{c}0.75 \text { (0.55 to } \\
1.01)\end{array}$ & $\begin{array}{l}1.06(0.51 \text { to } \\
2.19)\end{array}$ \\
\hline $\begin{array}{l}\text { Death or } \\
\text { myocardial } \\
\text { infarction: }\end{array}$ & $\begin{array}{l}63 \text { trials with } \\
174559 \mathrm{PY}\end{array}$ & $\begin{array}{l}53 \text { trials with } \\
184970 \mathrm{PY}\end{array}$ & $\begin{array}{l}61 \text { trials with } \\
190173 \mathrm{PY}\end{array}$ & $\begin{array}{l}71 \text { trials with } \\
172346 \mathrm{PY}\end{array}$ & $\begin{array}{l}71 \text { trials with } \\
148563 \mathrm{PY}\end{array}$ & $\begin{array}{l}72 \text { trials with } \\
194454 \mathrm{PY}\end{array}$ & $\begin{array}{l}49 \text { trials with } \\
204959 \text { PY }\end{array}$ & $\begin{array}{l}88 \text { trials with } \\
233030 \mathrm{PY}\end{array}$ & \\
\hline $\begin{array}{l}\text { CABG } v \text { medical } \\
\text { treatment }\end{array}$ & $\begin{array}{c}0.79 \text { (0.60 to } \\
0.98)\end{array}$ & $\begin{array}{c}0.81 \text { (0.66 to } \\
1.03)\end{array}$ & $\begin{array}{c}0.82(0.70 \text { to } \\
0.95)\end{array}$ & - & $\begin{array}{l}0.83(0.71 \text { to } \\
0.98)\end{array}$ & $\begin{array}{c}0.77 \text { (0.65 to } \\
0.90)\end{array}$ & $\begin{array}{c}0.80(0.68 \text { to } \\
0.95)\end{array}$ & $\begin{array}{c}0.81 \text { (0.70 to } \\
0.94)\end{array}$ & $\begin{array}{c}0.76(0.37 \text { to } \\
1.48)\end{array}$ \\
\hline $\begin{array}{l}\text { PTCA } v \text { medical } \\
\text { treatment }\end{array}$ & $\begin{array}{c}0.86 \text { (0.68 to } \\
1.06)\end{array}$ & $\begin{array}{c}0.87 \text { (0.68 to } \\
1.11)\end{array}$ & $\begin{array}{c}0.84 \text { (0.71 to } \\
1.00)\end{array}$ & $\begin{array}{c}0.87(0.71 \text { to } \\
1.05)\end{array}$ & $\begin{array}{l}0.83 \text { (0.69 to } \\
0.98)\end{array}$ & $\begin{array}{c}0.81 \text { (0.68 to } \\
0.98)\end{array}$ & $\begin{array}{c}0.79(0.64 \text { to } \\
0.97)\end{array}$ & $\begin{array}{c}0.83(0.70 \text { to } \\
0.97)\end{array}$ & $\begin{array}{c}0.69(0.25 \text { to } \\
1.86)\end{array}$ \\
\hline $\begin{array}{l}\text { BMS } v \text { medical } \\
\text { treatment }\end{array}$ & $\begin{array}{c}0.96(0.76 \text { to } \\
1.17)\end{array}$ & $\begin{array}{c}1.01 \text { ( } 0.84 \text { to } \\
1.18)\end{array}$ & $\begin{array}{c}0.99(0.85 \text { to } \\
1.14)\end{array}$ & $\begin{array}{c}1.03 \text { (0.89 to } \\
1.18)\end{array}$ & $\begin{array}{c}0.97 \text { (0.81 to } \\
1.11)\end{array}$ & $\begin{array}{c}0.98(0.83 \text { to } \\
1.15)\end{array}$ & $\begin{array}{c}1.00(0.84 \text { to } \\
1.16)\end{array}$ & $\begin{array}{c}0.99(0.85 \text { to } \\
1.12)\end{array}$ & $\begin{array}{c}1.04(0.75 \text { to } \\
1.30)\end{array}$ \\
\hline
\end{tabular}


Table 3 (continued)

\begin{tabular}{|c|c|c|c|c|c|c|c|c|c|}
\hline \multirow[b]{2}{*}{$\begin{array}{l}\text { Outcomes by } \\
\text { interventions }\end{array}$} & \multicolumn{8}{|c|}{ Network meta-analysis } & \multirow[b]{2}{*}{$\begin{array}{c}\text { Conventional } \\
\text { meta-analysis }\end{array}$} \\
\hline & $\begin{array}{l}\text { Allocation } \\
\text { concealed }\end{array}$ & $\begin{array}{l}\text { Adjudication } \\
\text { blinded }\end{array}$ & $\begin{array}{c}\text { Intention to } \\
\text { treat } \\
\text { analysis }\end{array}$ & $\begin{array}{l}\text { Excluding } \\
\text { CABG trials }\end{array}$ & $\begin{array}{l}\text { Excluding all } \\
\text { comer and } \\
\text { post-MI trials }\end{array}$ & $\begin{array}{l}\text { Trials with } \\
\leq 10 \% \text { lost to } \\
\text { follow-up }\end{array}$ & $\begin{array}{l}\text { Trials with } \\
\geq 24 \text { months } \\
\text { of follow-up }\end{array}$ & All trials & \\
\hline $\begin{array}{l}\text { PES } v \text { medical } \\
\text { treatment }\end{array}$ & $\begin{array}{c}1.01(0.77 \text { to } \\
1.26)\end{array}$ & $\begin{array}{c}1.01(0.79 \text { to } \\
1.25)\end{array}$ & $\begin{array}{c}1.15(0.89 \text { to } \\
1.42)\end{array}$ & $\begin{array}{c}1.02(0.82 \text { to } \\
1.22)\end{array}$ & $\begin{array}{c}1.11(0.88 \text { to } \\
1.36)\end{array}$ & $\begin{array}{c}1.05 \text { (0.86 to } \\
1.27)\end{array}$ & $\begin{array}{c}1.08(0.87 \text { to } \\
1.35)\end{array}$ & $\begin{array}{c}1.06(0.87 \text { to } \\
1.27)\end{array}$ & - \\
\hline $\begin{array}{l}\text { SES } v \text { medical } \\
\text { treatment }\end{array}$ & $\begin{array}{c}0.88(0.67 \text { to } \\
1.10)\end{array}$ & $\begin{array}{c}0.92(0.73 \text { to } \\
1.12)\end{array}$ & $\begin{array}{c}1.02(0.81 \text { to } \\
1.24)\end{array}$ & $\begin{array}{c}0.91(0.74 \text { to } \\
1.10)\end{array}$ & $\begin{array}{c}1.04(0.83 \text { to } \\
1.26)\end{array}$ & $\begin{array}{c}0.97 \text { (0.79 to } \\
1.17)\end{array}$ & $\begin{array}{c}0.97(0.78 \text { to } \\
1.19)\end{array}$ & $\begin{array}{c}0.96(0.79 \text { to } \\
1.13)\end{array}$ & - \\
\hline $\begin{array}{l}\text { E-ZES } v \text { medical } \\
\text { treatment }\end{array}$ & $\begin{array}{c}0.83(0.62 \text { to } \\
1.07)\end{array}$ & $\begin{array}{c}0.82(0.62 \text { to } \\
1.04)\end{array}$ & $\begin{array}{c}0.97(0.73 \text { to } \\
1.23)\end{array}$ & $\begin{array}{c}0.83(0.65 \text { to } \\
1.03)\end{array}$ & $\begin{array}{c}0.79(0.58 \text { to } \\
1.04)\end{array}$ & $\begin{array}{c}0.86(0.68 \text { to } \\
1.07)\end{array}$ & $\begin{array}{c}0.87(0.66 \text { to } \\
1.10)\end{array}$ & $\begin{array}{c}0.85(0.67 \text { to } \\
1.05)\end{array}$ & - \\
\hline \multicolumn{10}{|l|}{$\begin{array}{l}\text { New generation } \\
\text { DES: }\end{array}$} \\
\hline $\begin{array}{l}\text { R-ZES } v \text { medical } \\
\text { treatment }\end{array}$ & $\begin{array}{c}0.77 \text { (0.53 to } \\
1.08)\end{array}$ & $\begin{array}{c}0.79(0.56 \text { to } \\
1.10)\end{array}$ & NA & $\begin{array}{c}0.78(0.57 \text { to } \\
1.05)\end{array}$ & NA & $\begin{array}{c}0.81(0.59 \text { to } \\
1.09)\end{array}$ & $\begin{array}{c}0.79(0.49 \text { to } \\
1.26)\end{array}$ & $\begin{array}{c}0.81(0.59 \text { to } \\
1.10)\end{array}$ & - \\
\hline $\begin{array}{l}\text { EES } v \text { medical } \\
\text { treatment }\end{array}$ & $\begin{array}{c}0.75(0.56 \text { to } \\
0.96)\end{array}$ & $\begin{array}{c}0.78(0.60 \text { to } \\
0.97)\end{array}$ & $\begin{array}{c}0.90(0.49 \text { to } \\
1.63)\end{array}$ & $\begin{array}{c}0.76(0.60 \text { to } \\
0.93)\end{array}$ & $\begin{array}{c}0.78(0.58 \text { to } \\
1.03)\end{array}$ & $\begin{array}{c}0.78(0.62 \text { to } \\
0.96)\end{array}$ & $\begin{array}{c}0.80(0.62 \text { to } \\
1.03)\end{array}$ & $\begin{array}{c}0.78(0.63 \text { to } \\
0.96)\end{array}$ & $\begin{array}{c}0.87(0.43 \text { to } \\
1.74)\end{array}$ \\
\hline $\begin{array}{l}\text { Subsequent } \\
\text { revascularisation: }\end{array}$ & $\begin{array}{l}66 \text { trials with } \\
183001 \mathrm{PY}\end{array}$ & $\begin{array}{l}53 \text { trials with } \\
185573 \text { PY }\end{array}$ & $\begin{array}{l}65 \text { trials with } \\
189933 \mathrm{PY}\end{array}$ & $\begin{array}{l}75 \text { trials with } \\
176020 \mathrm{PY}\end{array}$ & $\begin{array}{l}79 \text { trials with } \\
155514 \text { PY }\end{array}$ & $\begin{array}{l}75 \text { trials with } \\
195561 \mathrm{PY}\end{array}$ & $\begin{array}{l}49 \text { trials with } \\
205311 \text { PY }\end{array}$ & $\begin{array}{l}94 \text { trials with } \\
234693 \text { PY }\end{array}$ & \\
\hline $\begin{array}{l}\text { CABG } v \text { medical } \\
\text { treatment }\end{array}$ & $\begin{array}{c}0.16(0.12 \text { to } \\
0.21)\end{array}$ & $\begin{array}{c}0.17(0.14 \text { to } \\
0.20)\end{array}$ & $\begin{array}{c}0.17(0.14 \text { to } \\
0.21)\end{array}$ & - & $\begin{array}{c}0.16(0.13 \text { to } \\
0.20)\end{array}$ & $\begin{array}{c}0.15(0.12 \text { to } \\
0.19)\end{array}$ & $\begin{array}{c}0.18(0.15 \text { to } \\
0.21)\end{array}$ & $\begin{array}{c}0.16(0.13 \text { to } \\
0.20)\end{array}$ & $\begin{array}{c}0.17(0.09 \text { to } \\
0.28)\end{array}$ \\
\hline $\begin{array}{l}\text { PTCA } v \text { medical } \\
\text { treatment } \\
\end{array}$ & $\begin{array}{c}0.87 \text { (0.68 to } \\
1.11)\end{array}$ & $\begin{array}{c}0.87(0.71 \text { to } \\
1.05)\end{array}$ & $\begin{array}{c}0.93(0.77 \text { to } \\
1.12)\end{array}$ & $\begin{array}{c}0.92(0.78 \text { to } \\
1.08)\end{array}$ & $\begin{array}{c}0.97(0.80 \text { to } \\
1.16)\end{array}$ & $\begin{array}{c}0.94(0.76 \text { to } \\
1.16)\end{array}$ & $\begin{array}{c}0.93(0.77 \text { to } \\
1.11)\end{array}$ & $\begin{array}{c}0.97(0.82 \text { to } \\
1.16)\end{array}$ & $\begin{array}{c}0.87(0.62 \text { to } \\
1.26)\end{array}$ \\
\hline $\begin{array}{l}\text { BMS } v \text { medical } \\
\text { treatment }\end{array}$ & $\begin{array}{c}0.63(0.50 \text { to } \\
0.81)\end{array}$ & $\begin{array}{c}0.70(0.61 \text { to } \\
0.81)\end{array}$ & $\begin{array}{c}0.74(0.62 \text { to } \\
0.88)\end{array}$ & $\begin{array}{c}0.65(0.56 \text { to } \\
0.76)\end{array}$ & $\begin{array}{c}0.69(0.58 \text { to } \\
0.82)\end{array}$ & $\begin{array}{c}0.66(0.53 \text { to } \\
0.82)\end{array}$ & $\begin{array}{c}0.71(0.61 \text { to } \\
0.82)\end{array}$ & $\begin{array}{c}0.69(0.59 \text { to } \\
0.82)\end{array}$ & $\begin{array}{c}0.76(0.49 \text { to } \\
1.23)\end{array}$ \\
\hline \multicolumn{10}{|l|}{$\begin{array}{l}\text { Early generation } \\
\text { DES: }\end{array}$} \\
\hline $\begin{array}{l}\text { PES } v \text { medical } \\
\text { treatment }\end{array}$ & $\begin{array}{c}0.40(0.30 \text { to } \\
0.54)\end{array}$ & $\begin{array}{c}0.47 \text { (0.39 to } \\
0.58)\end{array}$ & $\begin{array}{c}0.43(0.33 \text { to } \\
0.57)\end{array}$ & $\begin{array}{c}0.41(0.33 \text { to } \\
0.50)\end{array}$ & $\begin{array}{c}0.44(0.34 \text { to } \\
0.57)\end{array}$ & $\begin{array}{c}0.41(0.32 \text { to } \\
0.54)\end{array}$ & $\begin{array}{c}0.41(0.33 \text { to } \\
0.52)\end{array}$ & $\begin{array}{c}0.44(0.35 \text { to } \\
0.55)\end{array}$ & - \\
\hline $\begin{array}{l}\text { SES } v \text { medical } \\
\text { treatment }\end{array}$ & $\begin{array}{c}0.26(0.20 \text { to } \\
0.35)\end{array}$ & $\begin{array}{c}0.32(0.27 \text { to } \\
0.39)\end{array}$ & $\begin{array}{c}0.29(0.23 \text { to } \\
0.38)\end{array}$ & $\begin{array}{c}0.26(0.21 \text { to } \\
0.32)\end{array}$ & $\begin{array}{c}0.28(0.22 \text { to } \\
0.36)\end{array}$ & $\begin{array}{c}0.27(0.21 \text { to } \\
0.35)\end{array}$ & $\begin{array}{c}0.33(0.27 \text { to } \\
0.40)\end{array}$ & $\begin{array}{c}0.29(0.24 \text { to } \\
0.36)\end{array}$ & - \\
\hline $\begin{array}{l}\text { E-ZES } v \text { medical } \\
\text { treatment }\end{array}$ & $\begin{array}{c}0.34(0.24 \text { to } \\
0.49)\end{array}$ & $\begin{array}{c}0.40(0.32 \text { to } \\
0.51)\end{array}$ & $\begin{array}{c}0.39(0.28 \text { to } \\
0.54)\end{array}$ & $\begin{array}{c}0.34(0.27 \text { to } \\
0.44)\end{array}$ & $\begin{array}{c}0.38(0.27 \text { to } \\
0.54)\end{array}$ & $\begin{array}{c}0.36(0.26 \text { to } \\
0.50)\end{array}$ & $\begin{array}{c}0.39(0.30 \text { to } \\
0.51)\end{array}$ & $\begin{array}{c}0.38(0.29 \text { to } \\
0.51)\end{array}$ & - \\
\hline \multicolumn{10}{|l|}{$\begin{array}{l}\text { New generation } \\
\text { DES: }\end{array}$} \\
\hline $\begin{array}{l}\text { R-ZES } v \text { medical } \\
\text { treatment }\end{array}$ & $\begin{array}{c}0.24(0.15 \text { to } \\
0.38)\end{array}$ & $\begin{array}{c}0.29(0.20 \text { to } \\
0.42)\end{array}$ & NA & $\begin{array}{c}0.25(0.16 \text { to } \\
0.36)\end{array}$ & NA & $\begin{array}{c}0.25(0.15 \text { to } \\
0.39)\end{array}$ & $\begin{array}{c}0.31(0.19 \text { to } \\
0.49)\end{array}$ & $\begin{array}{c}0.26(0.17 \text { to } \\
0.40)\end{array}$ & - \\
\hline $\begin{array}{l}\text { EES } v \text { medical } \\
\text { treatment }\end{array}$ & $\begin{array}{c}0.24(0.18 \text { to } \\
0.33)\end{array}$ & $\begin{array}{c}0.29(0.23 \text { to } \\
0.36)\end{array}$ & $\begin{array}{c}0.27(0.07 \text { to } \\
0.95)\end{array}$ & $\begin{array}{c}0.25(0.20 \text { to } \\
0.31)\end{array}$ & $\begin{array}{c}0.30(0.22 \text { to } \\
0.42)\end{array}$ & $\begin{array}{c}0.26(0.19 \text { to } \\
0.34)\end{array}$ & $\begin{array}{c}0.28(0.22 \text { to } \\
0.36)\end{array}$ & $\begin{array}{c}0.27(0.21 \text { to } \\
0.35)\end{array}$ & $\begin{array}{c}0.16(0.09 \text { to } \\
0.28)\end{array}$ \\
\hline
\end{tabular}

$\mathrm{CABG}=$ coronary artery bypass grafting; $\mathrm{Ml}=$ myocardial infarction; $\mathrm{PY}=$ patient years; $\mathrm{PTCA}=$ percutaneous transluminal coronary angioplasty; $\mathrm{BMS}=$ bare metal stent; DES=drug eluting stent; PES=paclitaxel eluting stent; SES=sirolimus eluting stent; R-ZES=zotarolimus eluting (Resolute) stent; E-ZES=zotarolimus eluting (Endeavor) stent; EES=everolimus eluting stent.

${ }^{*}$ Conventional random effects meta-analysis of direct randomised comparisons within trials. 


\section{Figures}

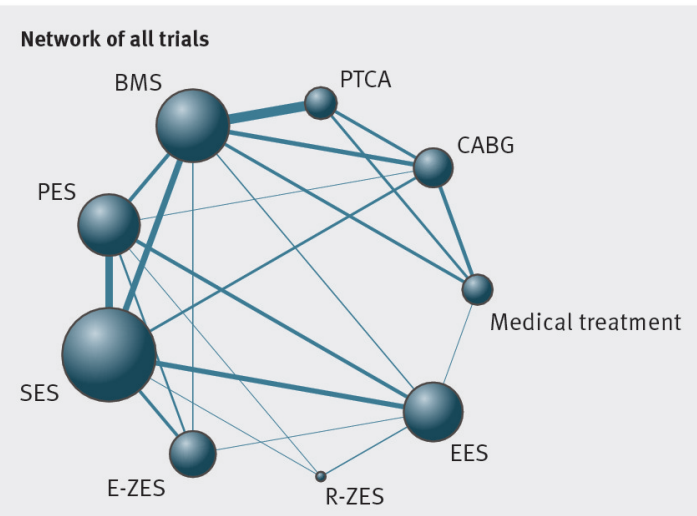

Network of contemporary trials

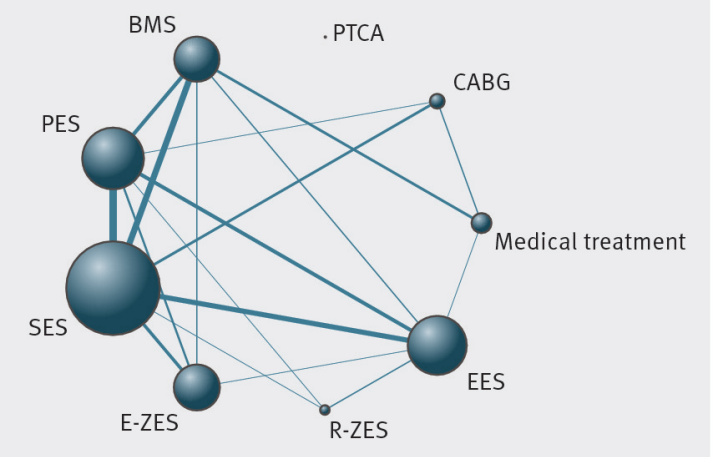

Fig 1 Network of comparisons included in analyses. Circle size is proportional to number of randomised patients and reflects sample size, whereas line width is proportional to number of comparisons. $C A B G=$ coronary artery bypass grafting; PTCA=percutaneous transluminal coronary angioplasty; $B M S=$ bare metal stents; $P E S=$ paclitaxel eluting stent; SES=sirolimus eluting stent; E-ZES=zotarolimus eluting (Endeavor) stent; R-ZES=zotarolimus eluting (Resolute) stent; EES=everolimus eluting stent 


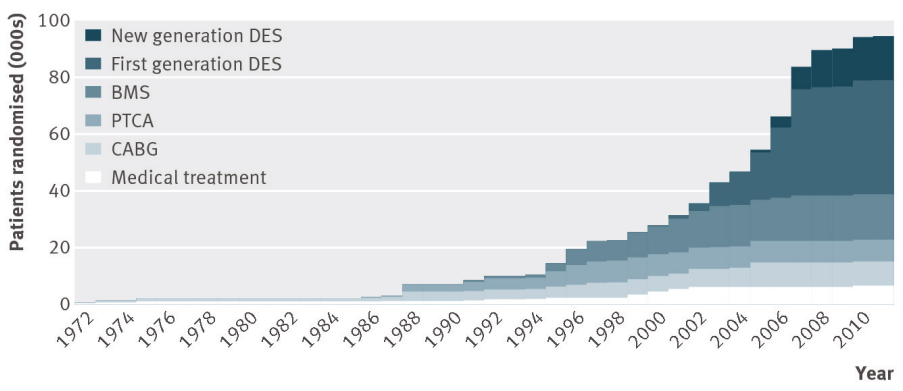

Fig 2 Accumulation of randomised evidence according to comparison over time. Cumulative number of patients randomly assigned to different types of intervention according to start of patient enrolment in each trial is presented. CABG=coronary 
artery bypass grafting; PTCA=percutaneous transluminal coronary angioplasty; BMS=bare metal stent; DES=drug eluting stent 


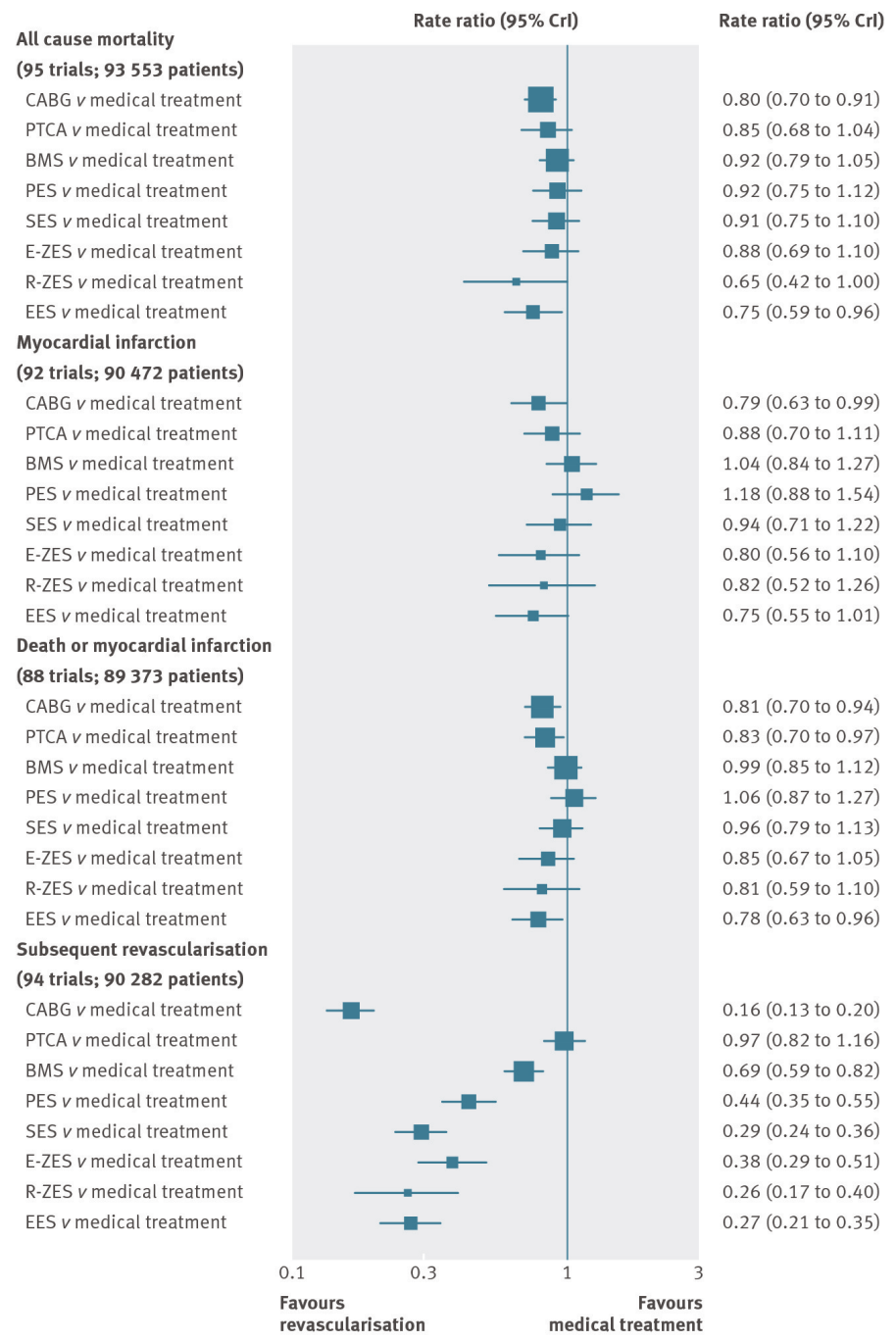

Fig 3 Estimated rate ratios (95\% credibility intervals) for mortality, myocardial infarction, the composite of death or myocardial infarction, and subsequent revascularisation from network meta-analyses for different revascularisation modalities compared with medical treatment-overall analyses. Square size is proportional to statistical precision of estimates. $C A B G=c o r o n a r y$ 
artery bypass grafting; PTCA=percutaneous transluminal coronary angioplasty; BMS=bare metal stents; PES=paclitaxel eluting stent; $S E S=$ sirolimus eluting stent; $E$-ZES=zotarolimus eluting (Endeavor) stent; R-ZES=zotarolimus eluting (Resolute) stent; EES=everolimus eluting stent 


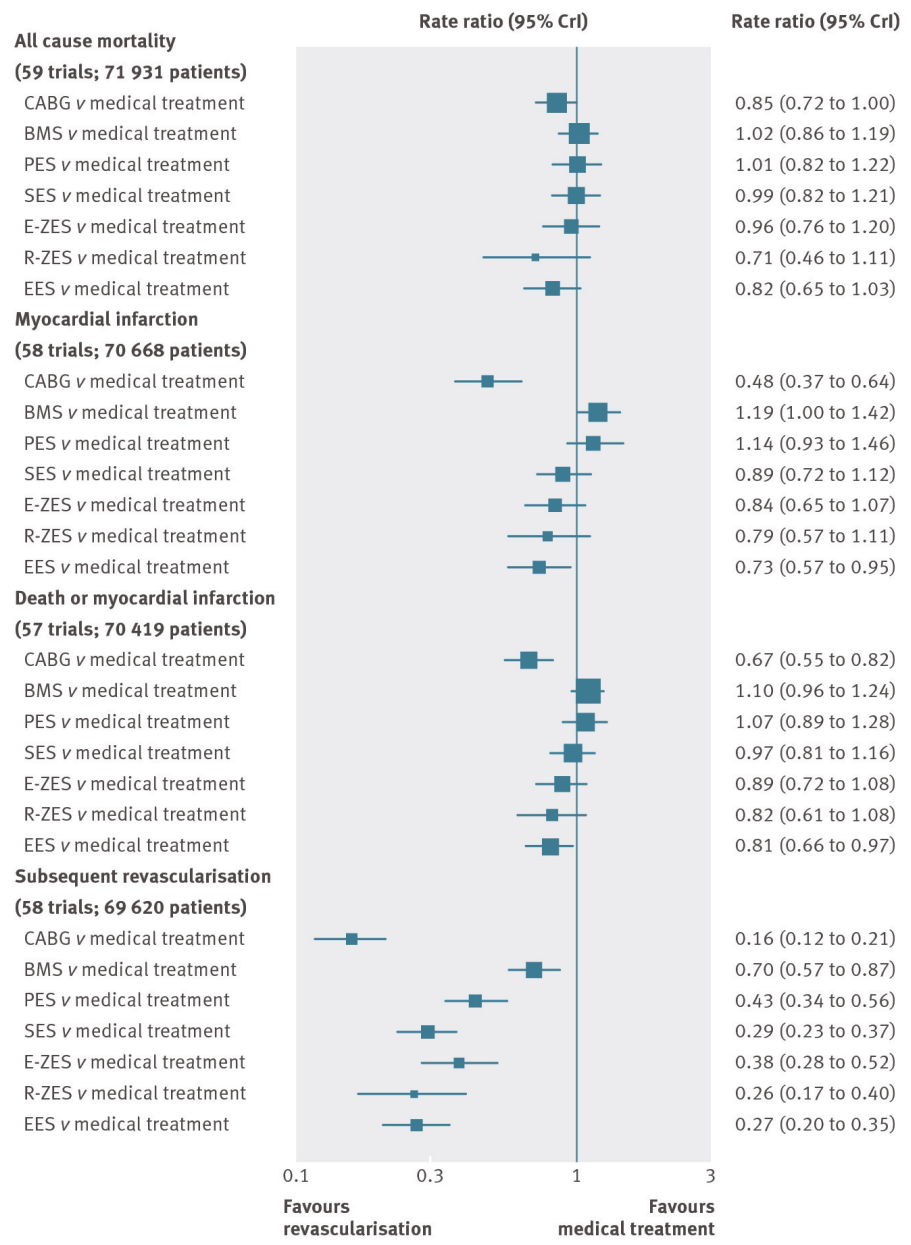

Fig 4 Estimated rate ratios (95\% credibility intervals) for mortality, myocardial infarction, the composite of death or myocardial infarction, and subsequent revascularisation from network meta-analyses for different revascularisation modalities compared with medical treatment-secondary analyses of contemporary trials initiated in 1999 or later. Square size is proportional to 
statistical precision of estimates. $\mathrm{CABG}=$ coronary artery bypass grafting; PTCA=percutaneous transluminal coronary angioplasty; BMS=bare metal stents; $P E S=$ paclitaxel eluting stent; $S E S=$ sirolimus eluting stent; E-ZES=zotarolimus eluting (Endeavor) stent; R-ZES=zotarolimus eluting (Resolute) stent; EES=everolimus eluting stent 